\title{
Directors' Connections, Financial Resources and Performance: An In-Depth Analysis of Canadian Companies
}

\author{
Saidatou Dicko ${ }^{1} \&$ Hassan El Ibrami ${ }^{1}$ \\ ${ }^{1}$ School of Management, University of Quebec in Montreal, Quebec, Canada \\ Correspondence: Hassan El Ibrami, School of Management, University of Quebec in Montreal, Quebec, H3C \\ 3P8, Canada. Tel: 1-514-987-3000 (ext. 1818). E-mail: el-ibrami.hassan@uqam.ca
}

Received: January 25, 2013 Accepted: March 11, 2013 Online Published: April 18, 2013

doi:10.5539/ijbm.v8n10p1 URL: http://dx.doi.org/10.5539/ijbm.v8n10p1

\begin{abstract}
Despite numerous studies, there is still no consensus about the impact of the board on firm performance. Previous research has focused mainly on the economic and financial aspects of the director's role, but scant attention has been paid to its relational aspect. Some authors have suggested that directors' social networks (connections) could be used to help the firm acquire external resources. This paper delves into the impact of three types of director connections on the firm's resources and financial performance. Based on a random sample of Canadian firms, our results show that directors' economic and political connections have a positive and significant impact on firm debt and that each type of connection they have (economic, political and social) affects firm financial performance.
\end{abstract}

Keywords: directors' connections, financial performance, financial resources, firm

\section{Introduction}

The board of directors has been examined extensively over the past decades, but there is still no consensus about its impact on firm performance. Faced with this dilemma, some sociologists have suggested adopting a relational point of view instead of examining the board's economic and financial aspects, as most previous studies have done. This paper conforms to that suggestion.

This study covers relatively uncharted territory. As some authors have suggested that directors' social networks (connections) may be used to help the firm acquire external resources (Dicko, 2011; Faccio, 2006), we decided to conduct an in-depth investigation on the impact of three types of directors' connections on firm resources and financial performance.

We hypothesize that directors' connections have a positive impact on the firm's principal financial resources (equity and long-term debt) and financial performance (return on assets, return on equity and market-to-book value). The research was carried out on a sample of randomly selected Canadian firms and covered data for the 2006-2011 period.

Our results vary according to the chosen statistical analysis method. While linear regression shows that directors' economic and political connections have a positive and significant impact on firm debt, only general linear results show that directors' connections (economic, political and social) have a positive and significant impact on firm financial performance.

\section{Theoretical Foundations, Literature Review and Hypotheses}

According to resource dependence theory, the role of directors is to connect a firm to its environment so it can obtain the main resources that it needs to survive and succeed (Pfeffer and Salancik, 1978). To connect a firm to resources, directors must have prior connections. Previous studies have shown that candidates are nominated to the board of directors mainly on the basis of their social capital (or social network) (Maman, 2000; Lester, 2003). Therefore, some authors argue that firms use their directors' connections to obtain resources (Breton and Pesqueux, 2006; Kim and Cannella, 2008; Dicko, 2011).

Social capital theory (Bourdieu, 1979; 1985) affirms that an individual can have different types of relationships or connections-economic (and financial), political and social. All of these connections may lead to several forms of benefits. Among studies performed on the role of the board of directors, there has been scant research on 
directors' economic and social connections, and the simultaneous integrated impact these three types of connections may have (economic, political and social). Rather, much of the focus has been on directors' political connections and board interlocking, which can be considered a type of economic connection.

In addition, there is little information on the direct impact of directors' connections on the firm's resource acquisition; instead, studies examine how these connections impact on a firm's financial performance. Our study investigates the simultaneous influence of the economic, political and social connections of directors on the firm's main financial resources, and then on its financial performance.

\subsection{Directors' Economic Connections and Financial Resources and Firm Performance}

Economic connections are relationships with companies and financial institutions. Previous literature has looked at the influence of board interlocking on a firm's financial performance, but with mitigated results. While most studies found a positive impact on a firm's performance (Koenig etal., 1979; Burt, 1980; Mintz and Schwartz, 1981; Mariolis and Jones, 1982; Ornstein, 1984; Richardson, 1987; Mizruchi and Stearns, 1988; Lang and Lockhart, 1990; Stearns and Mizruchi, 1993), some findings were to the contrary (Allen, 1974; Kim, 2005). As board interlocking involves companies sharing directors, it has been examined from the firm's perspective. Studied from the directors' perspective, however, it can be viewed as an aspect of directors' overall economic connections. Accordingly, we make the following hypotheses:

$\mathrm{H}_{1 \mathrm{a}}$ : Directors' economic connections have a direct and positive impact on the firm's financial resources.

$\mathrm{H}_{1 \mathrm{~b}}$ : The firm's financial resources have a direct and positive impact on firm performance.

$\mathrm{H}_{1 \mathrm{c}}$ : Directors' economic connections have an indirect and positive impact on firm performance.

\subsection{Directors' Political Connections and Their Impact on Financial Resources and Firm Performance}

Political connections are connections with political parties, political actors and the government. According to Faccio (2006), political connections can give firms many forms of benefits such as preferential treatment by government-owned businesses (including banks and raw material producers), lower tax rates, preferential treatment in competitions for government contracts, less stringent regulatory oversight of the company in question or stiffer regulatory oversight of its rivals, and much more. Several studies have demonstrated the positive impact of political connections on firm performance.

After examining 450 politically connected firms from 35 countries, Faccio et al. (2006) demonstrated that: 1) Politically connected firms are significantly more likely to be bailed out than similar non-connected firms; 2) Politically connected firms are disproportionately more likely to be bailed out when the International Monetary Fund (or the World Bank) provides the firm's home government with financial assistance; 3) Among bailed-out firms, those that are politically connected are in significantly worse financial shape than their non-connected peers at the time of and following the bailout. For Charumilind et al. (2008), politically connected firms have greater access to long-term debt than their non-connected counterparts. In the same vein, Claessens et al. (2008) showed that Brazilian firms that gave contributions to elected federal deputies during the 1998 and 2002 elections experienced higher stock returns than firms that did not. From the data of the S\&P 500 companies, Goldman et al. (2009) noted a positive abnormal stock return following the announcement of the nomination of a politically connected individual to the board of directors. They also found that companies connected to the U.S. Republican Party increased in value and companies connected to the U.S. Democratic Party decreased in value after the Republican electoral win in 2000.

The foregoing studies assumed that firms are either politically connected or not and concluded that the fact of being politically connected has a positive impact on the firm. In our study, we focus on the extent of the connection (i.e., in terms of numbers). Accordingly, we hypothesize that:

$\mathrm{H}_{2 \mathrm{a}}$ : Directors' political connections have a direct and positive impact on the firm's financial resources.

$\mathrm{H}_{2 b}$ : The firm's financial resources have a direct and positive impact on firm performance.

$\mathrm{H}_{2 \mathrm{c}}$ : Directors' political connections have an indirect and positive impact on firm performance.

\subsection{Directors'Social Connections, Financial Resources and Firm Performance}

Very little is known about the effect of directors' social connections, which are their affiliations with charity organizations, non-profit organizations, clubs and associations. Dicko (2011) argued that such connections can give directors access to economic and political connections; the same idea is sustained by Bourdieu (1985) in his social capital theory. Kim (2005) found that in the Korean context, directors who belonged to a network of elitist schools had a positive but moderate impact on a firm's financial performance. Therefore, we hypothesize that: 
$\mathrm{H}_{3 \mathrm{a}}$ : Directors' social connections have a direct and positive impact on the firm's financial resources.

$\mathrm{H}_{3 \mathrm{~b}}$ : The firm's financial resources have a direct and positive impact on firm performance.

$\mathrm{H}_{3 \mathrm{c}}$ : Directors' social connections have an indirect and positive impact on the firm's performance.

\section{Methodology}

The following is a description of the sample, analysis model and variable measures used in this study.

\subsection{Sample}

The sample consisted of a selection of Canadian companies in the Compustat database. Out of about 1,200 companies, we randomly selected the first 300 , based on their alphabetical classification. The study looked at information from 2006 to 2010, since we were interested in the most recent data. As a result of the random selection, the sample included a wide range of company sizes. Whereas most studies on directors' connections (especially board interlocking) involved large companies, it is our belief that social networking also occurs in smaller-sized companies. In addition, the Canadian context interested us since other investigations on directors' connections were carried out mainly on U.S. companies.

\subsection{Analysis Model}

Our main objective was to show that directors' connections contribute to increasing a firm's financial resources, which in turn positively influences its performance. Therefore, we use the following simultaneous equation model:

$$
\begin{gathered}
\text { Level of financial resources }=\text { Directors' economic, political and social connections }+ \text { Control variables }+\varepsilon(1) \\
\text { Performance }=\text { Level of financial resources }+ \text { Directors' economic, political and social connections }+ \text { Control } \\
\text { variables }+\varepsilon
\end{gathered}
$$

In the literature review section, it was noted that directors' connections can influence a firm's financial performance. It is therefore necessary to include directors' connections in both equations.

\subsection{Variables and Measurement}

\subsubsection{Level of Financial Resources}

According to Dicko (2011), directors make it possible for companies to obtain various resources through their connections, whether financial (equity and financial debt), commercial (commercial contracts), technical, political (by influencing the competitive field and regulations, lowering tax rates) or social (positive image, improved legitimacy). The focus here is on financial resources because they can be measured more easily than other types of resources. Each firm has two main long-term financial resources: shareholder equity and financial debt. The variable level of financial resources is measured by the natural logarithm of long-term financial debt and equity.

\subsubsection{Directors' Connections}

This variable is divided into three components:

$>$ Economic connections: an executive or director position in the company;

$>$ Political connections: membership or leadership in and/or financial contributions to political parties, a minister, or a top government position or parliament membership;

Social connections: membership in clubs and associations (professional or otherwise), membership or financial contribution to a charity or non-profit organization (foundations, universities and other academic organizations).

Prior studies concentrated on the existence of such connections. For example, in most political connection studies, this variable is measured by a dichotomous variable that takes the value 1 if the firm is politically connected and 0 if it is not. The distinguishing feature of our study is that it focuses on the nature and extent of directors' connections. Accordingly, to measure our variable, we assigned a value of 1 to each director's connection, according to the type of connection. Each firm's score is the sum of all of its directors' connection scores.

\subsubsection{Firm Financial Performance}

In board of directors' literature, there is no consensus on how to measure firm financial performance. We chose to use three measures: return on assets (ROA), return on equity (ROE) and market-to-book value (MTBV). A statistical analysis was performed separately for each type of financial performance measure. 


\subsubsection{Control Variables}

As control variables, we included those that have proven relevance such as size of firm (measured by the natural logarithm of total revenue), size of board of directors (measured by the number of directors on the board), independence of board of directors (measured by the number of independent directors out of the total number of directors), duality ( 1 if the CEO and board chair positions are held by the same person and 0 if it is not) and industry (dummy variable). For the industry variable, given that we were investigating Canadian companies, we chose the nine categories on Sedar (www.sedar.com): 1- Communications and Media, 2- Consumer Products, 3Financial Services, 4- Industrial Products, 5- Junior Natural Resources, 6- Merchandising, 7- Metals and Minerals, 8- Oil and Gas, and 9- Utilities. A few changes were made by merging Consumer Products with Merchandising and Junior Natural Resources with Metals and Minerals, and adding an "Others" category for the activities that were not taken into account. Lastly, we assigned eight categories to our dummy industry variable.

Given that some authors have stressed the importance of the industry on the firm's need for resources and on some corporate governance issues (Lang and Lockhart 1990), we decided to integrate three other control variables that interact with directors' connections and the industry: interaction between directors' economic connections and the industry (EcqIndustry); interaction between directors' political connections and the industry (PolIndustry); and interaction between directors' social connections and the industry (SocIndustry).

The detailed model with the ROA is the following:

Ln Long-term debt $($ LnLTDebt $)=$ Directors' economic connections $(D E C)+$ Directors' political connections $(D P C)+$ Directors' social connections (DSC) + Board size (BDSize) + Board independence (BDInd) + Duality + Ln Total Revenue (LnRevenue) + Industry + EcqIndustry + PolIndustry + SocIndustry $+\varepsilon$

Ln Equity = Directors' economic connections $(D E C)+$ Directors' political connections $(D P C)+$ Directors' social connections $(D S C)+$ Board size + Board independence + Duality + Ln Total Revenue + Industry + EcqIndustry + PolIndustry + SocIndustry $+\varepsilon$

$R O A=$ Ln Equity + Ln Long-term debt + Directors' economic connections $(D E C)+$ Directors' political connections $(D P C)+$ Directors' social connections $(D S C)+$ Board size + Board independence + Duality + Ln Total Revenue + Industry + EcqIndustry + PolIndustry + SocIndustry $+\varepsilon$

The detailed model with the ROE is the following:

Ln Long-term debt $=$ Directors' economic connections $(D E C)+$ Directors' political connections $(D P C)+$ Directors' social connections (DSC) + Board size + Board independence + Duality + Ln Total Revenue + Industry + EcqIndustry + PolIndustry + SocIndustry $+\varepsilon$

Ln Equity = Directors' economic connections $(D E C)+$ Directors' political connections $(D P C)+$ Directors social connections $(D S C)+$ Board size + Board independence + Duality + Ln Total Revenue + Industry + EcqIndustry + PolIndustry + SocIndustry $+\varepsilon$

$R O E=$ Ln Equity + Ln Long-term debt + Directors' economic connections $(D E C)+$ Directors' political connections $(D P C)+$ Directors' social connections $(D S C)+$ Board size + Board independence + Duality + Ln Total Revenue + Industry + EcqIndustry + PolIndustry + SocIndustry $+\varepsilon$

The detailed model with the market-to-book value is the following:

Ln Long-term debt $=$ Directors' economic connections $(D E C)+$ Directors' political connections $(D P C)+$ Directors' social connections $(D S C)+$ Board size + Board independence + Duality + Ln Total Revenue + Industry + EcqIndustry + PolIndustry + SocIndustry $+\varepsilon$

Ln Equity = Directors' economic connections $(D E C)+$ Directors' political connections $(D P C)+$ Directors' social connections $(D S C)+$ Board size + Board independence + Duality + Ln Total Revenue + Industry + EcqIndustry + PolIndustry + SocIndustry $+\varepsilon$

Market-to-book value $(M T B V)=$ Ln Equity + Ln Long-term debt + Directors' economic connections $(D E C)+$ Directors' political connections (DPC) + Directors' social connections (DSC) + Board size + Board independence + Duality + Ln Total Revenue + Industry + EcqIndustry + PolIndustry + SocIndustry $+\varepsilon$

\section{Analysis and Results}

\subsection{Descriptive and Correlation Analyses}

The descriptive statistics on director connections by industry (Table 1) show that "Communications and Media" is, on average, the most connected industry in terms of economic and social connections. In terms of directors' economic connections, the second industry with the most connections is "Oil and Gas", followed by "Financial 
Services" (third), "Metals and Minerals" (fourth), "Consumer Products and Merchandising" (fifth), "Industrial Products" (sixth) and "Utilities" (seventh).

Table 1. Descriptive statistics on directors' connections by industry

\begin{tabular}{|c|c|c|c|c|c|c|c|c|}
\hline \multirow{2}{*}{\multicolumn{2}{|c|}{ Industry }} & \multirow[t]{2}{*}{$\mathrm{N}$} & \multicolumn{2}{|c|}{ DEC } & \multicolumn{2}{|c|}{ DPC } & \multicolumn{2}{|c|}{ DSC } \\
\hline & & & \multirow{2}{*}{$\begin{array}{l}\text { Mean } \\
89.54\end{array}$} & \multirow{2}{*}{$\begin{array}{c}\text { STDV } \\
70.12\end{array}$} & \multirow{2}{*}{$\begin{array}{c}\text { Mean } \\
0.65\end{array}$} & \multirow{2}{*}{$\begin{array}{c}\text { STDV } \\
1.37\end{array}$} & \multirow{2}{*}{$\begin{array}{c}\text { Mean } \\
3.24\end{array}$} & \multirow{2}{*}{$\begin{array}{c}\text { STDV } \\
5.98\end{array}$} \\
\hline 1 & Communications and Media & 37 & & & & & & \\
\hline 2 & Consumer products and Merchandising & 135 & 51.48 & 42.74 & 0.73 & 1.88 & 0.61 & 1.16 \\
\hline 3 & Financial Services & 132 & 58.12 & 58.10 & 0.61 & 1.87 & 0.77 & 1.48 \\
\hline 4 & Industrial Products & 75 & 46.93 & 30.23 & 0.13 & 0.50 & 0.73 & 1.44 \\
\hline 5 & Metals and Minerals & 173 & 52.42 & 30,53 & 0.41 & 1.31 & 0.24 & 0.54 \\
\hline 6 & Oil and Gas & 61 & 64.79 & 52.12 & 0.41 & 0.95 & 0.66 & 1.65 \\
\hline 7 & Utilities & 17 & 45.18 & 15.43 & 0.00 & 0.00 & 0.00 & 0.00 \\
\hline \multirow[t]{2}{*}{8} & Others & 141 & 66.09 & 69.01 & 1.06 & 2.90 & 1.05 & 1.56 \\
\hline & Total & 771 & 57.80 & 50.93 & 0.59 & 1.84 & 0.76 & 1.89 \\
\hline
\end{tabular}

In terms of political connections, "Consumer Products and Merchandising" is the most connected industry, followed by "Communications and Media" (second), "Financial Services" (third), "Metals and Minerals" (fourth), "Oil and Gas" (fifth), "Industrial Products" (sixth) and "Utilities (seventh).

In terms of social connections, on average, "Communications and Media" finished first, followed by "Financial Services" (second), "Industrial Products" (third), "Oil and Gas" (fourth), "Consumer Products and Merchandising" (fifth), "Metals and Minerals" (sixth) and "Utilities" (seventh). Among all industries, "Utilities" was the least connected in terms of all three types of directors' connections.

Table 2. Industry differences in terms of directors' connections: ANOVA results

\begin{tabular}{lcc}
\hline & F-Statistic & p-value \\
\hline DEC and Industry & 4.07 & 0.00 \\
DPC and Industry & 2.75 & 0.00 \\
DSC and Industry & 13.42 & 0.00 \\
\hline
\end{tabular}

The variance analysis presented in Table 2 shows that there are positive and highly significant differences among industries in terms of directors' economic, political and social connections.

Table 3. Correlation analyses

\begin{tabular}{lllllllll}
\hline & & 1 & 2 & 3 & 4 & 5 & 6 & 7 \\
\hline 1 & DEC & & & & & & & \\
2 & DPC & $0.52^{* * *}$ & & & & & & \\
3 & DSC & $0.37^{* * *}$ & $0.27^{* * *}$ & & & & & \\
4 & LnLTDebt & $0.25^{* * *}$ & $0.11^{* *}$ & $0.26^{* * *}$ & & & & \\
5 & LnEquity & $0.44^{* * *}$ & $0.23^{* * *}$ & $0.29^{* * *}$ & $0.82^{* * *}$ & & & \\
6 & ROA & -0.01 & -0.00 & -0.01 & $-0.08^{* *}$ & $0.36^{* * *}$ & & \\
7 & ROE & 0.06 & 0.07 & 0.06 & 0.04 & $0.40^{* * *}$ & $-0.53^{* * *}$ & \\
8 & MTBV & -0.06 & -0.04 & -0.04 & $-0.27^{* * *}$ & $-0.34^{* * *}$ & $-0.37^{* * *}$ & $0.26^{* * *}$ \\
\hline
\end{tabular}


According to Table 3, the correlation analyses demonstrate a positive and very significant relationship between directors' economic, political and social connections and the firm's main financial resources, debt $(25 \%, 11 \%$ and $26 \%$ respectively) and shareholder equity levels (44\%,23\% and 29\% respectively). These correlations are in keeping with hypotheses $\mathrm{H}_{1 \mathrm{a}}, \mathrm{H}_{2 \mathrm{a}}$ and $\mathrm{H}_{3 \mathrm{a}}$.

While debt levels have a negative and significant relationship with firm financial performance indicators (except for ROE, which is positive but not significant), on average, level of shareholder equity has a positive and very significant relationship with the ROA and ROE and a negative and very significant relationship with MTBV. These correlation results are mitigated with respect to hypotheses $\mathrm{H}_{1 \mathrm{~b}}, \mathrm{H}_{2 \mathrm{~b}}$ and $\mathrm{H}_{3 \mathrm{~b}}$.

Lastly, the correlation analyses show no significant relationship between directors' connections and firm financial performance indicators (ROA, ROE and MTBV), contradicting hypotheses $\mathrm{H}_{1 \mathrm{c}}, \mathrm{H}_{2 \mathrm{c}}$ and $\mathrm{H}_{3 \mathrm{c}}$.

\subsection{Linear Regression Results}

\subsubsection{Directors' Connections and Firm Financial Resources}

$\mathrm{H}_{1 \mathrm{a}}, \mathrm{H}_{2 \mathrm{a}}$ and $\mathrm{H}_{3 \mathrm{a}}$ predict a direct and positive impact of directors' connections on the firm's financial resources. According to Table 4, only directors' economic and political connections have a positive impact on debt level over five years (Ln Long-term debt), while directors' social connections do not have a significant impact. In a year-to-year comparison, only the impact of directors' economic connections remains significant in 2006 and 2007.

Table 4. Linear regression results

\begin{tabular}{lcccccc}
\hline \multicolumn{7}{c}{ Dependent Variable: Ln Long-Term Debt } \\
\hline Independent Variables & 2006 & 2007 & 2008 & 2009 & 2010 & Over 5 Years \\
DEC & & & & & & \\
DPC & $2.22^{* *}$ & $1.82^{*}$ & 1.36 & 0.84 & 0.24 & $3.04^{* * *}$ \\
DSC & 0.69 & 1.17 & 1.44 & 1.58 & 1.44 & $2.88^{* * *}$ \\
Control Variables & -1.24 & -0.50 & 0.47 & 0.81 & 0.79 & 0.17 \\
Duality & & & & & & \\
BDSize & -0.82 & -1.00 & $-1.65^{*}$ & $-2.63^{* * *}$ & -0.60 & $-3.05^{* * *}$ \\
BDInd & 1.14 & 0.90 & 0.70 & 0.09 & 0.43 & 1.475 \\
Ln Revenue & -0.73 & -1.20 & $-2.03^{* *}$ & -1.28 & -0.73 & $-2.68^{* * *}$ \\
Industry & $7.31^{* * *}$ & $5.70^{* * *}$ & $5.91^{* * *}$ & $8.02^{* * *}$ & $7.03^{* * *}$ & $15.58^{* * *}$ \\
Year & 1.18 & $1.68^{*}$ & 1.27 & $1.65^{*}$ & 1.03 & $3.01^{* * *}$ \\
EcqIndustry & & & & & & 1.23 \\
PolIndustry & -1.61 & -1.27 & -0.72 & -0.48 & -0.18 & $-1.94^{* *}$ \\
SocIndustry & -1.12 & -1.38 & $-1.91^{*}$ & -1.41 & -1.18 & $-3.24^{* * *}$ \\
$\mathrm{R}^{2}$ & $2.54^{* * *}$ & $1.86^{*}$ & 1.10 & 0.53 & 0.35 & $2.95^{* * *}$ \\
Adjusted $\mathrm{R}^{2}$ & $0.43^{* * *}$ & $0.36^{* * *}$ & $0.39^{* * *}$ & $0.46^{* * *}$ & $0.36^{* * *}$ & $0.39^{* * *}$ \\
\hline
\end{tabular}

Almost all the control variables have a very significant impact on debt level over five years, except for "BD size" and "Year". Therefore, "Duality" and "BD independence" have a negative and very significant impact on debt level, while the impact of "Ln revenue" and "Industry" is positive and very significant. When the economic and political connections of directors interact with the industry, their impact on debt level becomes negative and very significant. In Table 4 , all models have a relatively high (30\% to $46 \%)$ and very significant $\mathrm{R}^{2}$ and adjusted $\mathrm{R}^{2}$. 
Table 5. Linear regression results

\begin{tabular}{lcccccc}
\hline \multicolumn{7}{c}{ Dependent Variable: Ln Equity } \\
\hline Independent Variables & 2006 & 2007 & 2008 & 2009 & 2010 & Over 5 Years \\
DEC & & & & & & \\
DPC & -1.25 & -1.04 & -0.72 & -0.68 & $1.82^{*}$ & -0.83 \\
DSC & 0.88 & -0.01 & -0.00 & 0.81 & 0.16 & -0.09 \\
Control Variables & 1.57 & 0.70 & 0.68 & 0.08 & 0.79 & 0.45 \\
Duality & & & & & & \\
BDSize & 0.15 & -0.07 & 0.13 & $-3.00^{* * *}$ & -1.52 & $-3.10^{* * *}$ \\
BDInd & -0.34 & 0.54 & 1.35 & $4.00^{* * *}$ & $2.76^{* * *}$ & $5.18^{* * *}$ \\
Ln Revenue & $1.89^{*}$ & 1.21 & 0.70 & $1.87^{*}$ & $2.12^{* *}$ & $2.58^{* * *}$ \\
Industry & 0.28 & 1.34 & 0.79 & $5.24^{* * *}$ & $6.05^{* * *}$ & $7.16^{* * *}$ \\
Year & -0.98 & -1.06 & -0.40 & -0.57 & 1.21 & -0.70 \\
EcqIndustry & & & & & & -1.17 \\
PolIndustry & 1.47 & 0.37 & 0.02 & 0.44 & -1.29 & 0.05 \\
SocIndustry & -1.33 & -0.09 & -0.04 & -0.75 & -0.02 & 0.10 \\
$\mathrm{R}^{2}$ & -0.44 & 0.57 & 0.55 & 0.89 & 0.05 & 1.17 \\
Adjusted $\mathrm{R}^{2}$ & 0.06 & 0.06 & 0.05 & $0.43^{* * *}$ & $0.45^{* * *}$ & $0.18^{* * *}$ \\
\hline
\end{tabular}

In Table 5, none ofthe three types of directors' connections have a significant impact on shareholder equity level over five years (Ln Equity). Regarding control variables, "Duality" (negative impact), "BD size", "BD independence" and "Ln Revenue" (positive impact for the last three) have a very significant impact on shareholder equity level. The other control variables are not significant. Only the 2009, 2010 and over-five yearsmodel exhibit significant $R^{2}$ and adjusted $R^{2}$. When directors' connections interact with Industry, they have a negative and significant impact only on long-term debt, according to the linear regression results (Table 4).

In conclusion, according to Tables 4 and 5, only directors' economic and political connections have a positive and significant impact on firm debt, and none of their connections have a significant impact on firm equity. Therefore, $\mathrm{H}_{1 \mathrm{a}}$ and $\mathrm{H}_{2 \mathrm{a}}$ are partially confirmed, while $\mathrm{H}_{3 \mathrm{a}}$ is rejected.

\subsubsection{Firm Financial Resources and Financial Performance}

$\mathrm{H}_{1 b}, \mathrm{H}_{2 b}$ and $\mathrm{H}_{3 b}$ predict that financial resources have a positive and significant impact (Ln Long-term debt and Ln Equity) on financial performance (ROA, ROE and MTBV).

\subsubsection{Financial Resources and ROA}

According to Table 6, only debt level has a highly significant but negative impact on ROA in the over-five-years model and only for 2006, 2007, 2008 and 2009. Furthermore, only the over-five-years model results in a significant but very weak $\mathrm{R}^{2}$ and adjusted $\mathrm{R}^{2}$ (5\% and $3 \%$ respectively). Therefore, $\mathrm{H}_{1 \mathrm{~b}}, \mathrm{H}_{2 \mathrm{~b}}$ and $\mathrm{H}_{3 \mathrm{~b}}$ are rejected for the ROA. 
Table 6. Linear regression results

\begin{tabular}{lllllll}
\hline \multicolumn{7}{c}{ Dependent Variable: ROA } \\
\hline Independent Variables & 2006 & 2007 & 2008 & 2009 & 2010 & Over 5 Years \\
LnLTDebt & & & & & & \\
LnEquity & $-2.72^{* * *}$ & $-2.76^{* * *}$ & $-3.07^{* * *}$ & $-3.28^{* * *}$ & -0.27 & $-4.43^{* * *}$ \\
DEC & 0.05 & 0.11 & 0.39 & 0.82 & -0.88 & 0.42 \\
DPC & 0.52 & 0.43 & 0.35 & 0.36 & -0.76 & -0.19 \\
DSC & 0.02 & 0.14 & 0.25 & 0.21 & 0.24 & 0.39 \\
Control Variables & 0.19 & 0.36 & 0.59 & 0.60 & -0.03 & 0.68 \\
Duality & & & & & & \\
BDSize & 1.48 & 1.43 & 1.18 & 1.07 & -0.14 & $1.69^{*}$ \\
BDInd & 0.15 & 0.23 & 0.22 & -0.11 & $-1.77^{*}$ & $-1.68^{*}$ \\
Ln Revenue & 0.64 & 0.71 & 0.42 & -0.15 & -0.56 & -0.13 \\
Industry & $1.79^{*}$ & 1.42 & 1.64 & $2.23^{* *}$ & $3.37^{* * *}$ & $5.14^{* * *}$ \\
Year & 1.23 & 1.40 & 1.41 & 1.13 & $-1.78^{*}$ & 0.14 \\
EcqIndustry & & & & & & -0.10 \\
PolIndustry & -0.45 & -0.41 & -0.34 & -0.27 & 1.32 & 0.90 \\
SocIndustry & -0.14 & -0.16 & -0.30 & -0.16 & -0.61 & -0.78 \\
$\mathrm{R}^{2}$ & -0.25 & -0.46 & -0.61 & -0.54 & 0.06 & -0.84 \\
Adjusted R ${ }^{2}$ & 0.07 & 0.08 & 0.09 & 0.10 & 0.11 & $0.05^{* * *}$ \\
\hline
\end{tabular}

\subsubsection{Financial Resources and ROE}

Table 7 demonstrates that debt level in the over-five-years model (Ln Long-term debt) has a negative and very significant impact on ROE, but equity (Ln Equity) has a positive and very significant impact, observed only for 2006, 2007, 2008, 2009 and 2010. These results are normal because there is a correlation between ROE and equity. All the models in Table 7 display very significant $R^{2}$ and adjusted $\mathrm{R}^{2}$, ranging from $7 \%$ to $73 \%$. $\mathrm{H}_{1 \mathrm{~b}}, \mathrm{H}_{2 \mathrm{~b}}$ and $\mathrm{H}_{3 \mathrm{~b}}$ are partially supported for the ROE.

Table 7. Linear regression results

\begin{tabular}{lllllll}
\hline \multicolumn{7}{c}{ Dependent Variable: ROE } \\
\hline Independent Variables & 2006 & 2007 & 2008 & 2009 & 2010 & Over 5 Years \\
LnLTDebt & & & & & & \\
LnEquity & -0.06 & 0.34 & -0.11 & $-3.59^{* * *}$ & $-2.09^{* *}$ & $-2.81^{* * *}$ \\
DEC & $12.63^{* * *}$ & $18.99^{* * *}$ & $12.82^{* * *}$ & $5.74^{* * *}$ & $3.18^{* * *}$ & $8.45^{* * *}$ \\
DPC & 0.14 & -0.52 & 1.03 & -0.52 & 0.63 & 0.78 \\
DSC & -0.69 & -0.70 & -0.02 & 1.26 & 0.51 & 1.22 \\
Control Variables & -0.49 & -0.27 & -0.44 & 0.40 & 0.05 & 0.02 \\
Duality & & & & & & \\
BDSize & -0.34 & -0.10 & 0.32 & -0.92 & $2.20^{* *}$ & 1.44 \\
BDInd & 1.55 & 1.58 & 0.47 & $-1.69^{*}$ & $-2.31^{* *}$ & $-2.52^{* * *}$ \\
Ln Revenue & -0.91 & $-1.74^{*}$ & -0.82 & -1.53 & $-2.84^{* * *}$ & $-2.85^{* * *}$ \\
Industry & 0.72 & 1.59 & -0.92 & 1.64 & 1.27 & $1.77^{*}$ \\
Year & 0.34 & -1.15 & 1.25 & -1.06 & 0.42 & 0.02 \\
EcqIndustry & & & & & & 0.83 \\
PolIndustry & -1.33 & -0.32 & -0.64 & 0.82 & -0.31 & 0.10 \\
SocIndustry & 1.11 & 0.79 & -0.09 & -1.16 & -0.54 & -1.30 \\
$\mathrm{R}^{2}$ & 1.47 & 0.68 & 0.23 & 0.14 & 0.26 & 0.32 \\
Adjusted $\mathrm{R}^{2}$ & $0.53^{* * *}$ & $0.73^{* * *}$ & $0.54^{* * *}$ & $0.27^{* * *}$ & $0.15^{* *}$ & $0.10^{* * *}$ \\
\hline
\end{tabular}




\subsubsection{Financial Resources and MTBV}

Table 8 shows that neither of the two financial resources (Ln Long-term debt and Ln Equity) has a significant impact on MTBV except in 2009, when the negative impact of the Ln Equity is very significant. Therefore, $\mathrm{H}_{1 b}$, $\mathrm{H}_{2 b}$ and $\mathrm{H}_{3 \mathrm{~b}}$ are rejected for MTBV.

Table 8. Linear regression results

\begin{tabular}{|c|c|c|c|c|c|c|}
\hline \multicolumn{7}{|c|}{ Dependent Variable: MTBV } \\
\hline & 2006 & 2007 & 2008 & 2009 & 2010 & Over 5 Years \\
\hline \multicolumn{7}{|c|}{ Independent Variables } \\
\hline LnLTDebt & -0.46 & -0.18 & -0.13 & 0.57 & -0.28 & -0.57 \\
\hline LnEquity & 0.25 & 0.35 & 0.22 & $-3.91^{* * *}$ & -1.53 & -1.08 \\
\hline $\mathrm{DEC}$ & 0.01 & 0.30 & 0.65 & -0.00 & 0.77 & 0.29 \\
\hline $\mathrm{DPC}$ & 0.09 & 0.30 & 0.56 & 1.35 & 0.61 & 0.74 \\
\hline $\mathrm{DSC}$ & 0.03 & 0.48 & 0.17 & 0.69 & 0.93 & 0.68 \\
\hline \multicolumn{7}{|c|}{ Control Variables } \\
\hline Duality & 0.43 & 1.46 & $2.23^{* *}$ & 0.64 & $2.59^{* * *}$ & $2.20^{* *}$ \\
\hline BDSize & 0.69 & -0.72 & -1.00 & 0.48 & -0.94 & -0.31 \\
\hline BDInd & -0.33 & -1.57 & -1.08 & 0.15 & -1.31 & -1.53 \\
\hline Ln Revenue & -1.20 & -1.28 & $-1.78^{*}$ & -0.44 & 0.13 & $-1.99^{* *}$ \\
\hline Industry & 0.33 & 0.89 & 0.57 & 1.10 & 1.34 & 1.19 \\
\hline Year & & & & & & $-2.91^{* * *}$ \\
\hline EcqIndustry & -0.06 & -0.04 & -0.15 & 0.09 & -0.23 & 0.07 \\
\hline PolIndustry & -0.13 & -0.37 & -0.65 & -0.75 & -0.59 & -0.75 \\
\hline SocIndustry & -0.23 & -0.48 & -0.27 & -0.95 & -0.92 & -0.89 \\
\hline $\mathrm{R}^{2}$ & 0.03 & 0.07 & 0.10 & $0.18^{* * *}$ & $0.13^{*}$ & $0.04^{* * *}$ \\
\hline Adjusted $\mathrm{R}^{2}$ & -0.05 & -0.00 & 0.02 & $0.10^{* * *}$ & $0.05^{*}$ & $0.02^{* * *}$ \\
\hline
\end{tabular}

\subsubsection{Directors' Connections and Financial Performance}

$\mathrm{H}_{1 \mathrm{c}}, \mathrm{H}_{2 \mathrm{c}}$ and $\mathrm{H}_{3 \mathrm{c}}$ predict a positive and indirect impact of directors' connections on firm financial performance. Tables 6, 7 and 8 show that directors' connections have no significant impact on financial performance indicators (ROA, ROE and MTBV). $\mathrm{H}_{1 \mathrm{c}}, \mathrm{H}_{2 \mathrm{c}}$ and $\mathrm{H}_{3 \mathrm{c}}$ are therefore rejected.

The results from the linear regression analyses show that the interaction between directors' connections and industry has no significant impact on firm financial performance (Tables 6, 7, and 8).

\subsection{General Linear Model Results}

For further analyses, we performed a general linear model to reflect the impact of financial resources and directors' connections on financial performance. According to Table 9, debt level (Ln Long-term debt) has a positive and very significant impact on ROA, ROE and MTBV over five years. Equity level (Ln Equity) has a positive and very significant impact on ROE and MTBV but not on ROA.Directors' economic connections have a positive and significant impact on ROA, ROE and MTBV. Directors' political connections have a positive and very significant impact on MTBV and a slightly significant impact on ROA. Directors' social connections have only a positive and very significant impact on MTBV. 
Table 9. General linear model resultsover 5 years (2006-2010)

\begin{tabular}{llll}
\hline & \multicolumn{3}{c}{ Dependent Variables } \\
\cline { 2 - 4 } & ROA & ROE & MTBV \\
\hline Independent Variables & & & \\
LnLTDebt & $18.95^{* * *}$ & $13.48^{* * *}$ & $16.29^{* * *}$ \\
LnEquity & 0.68 & $9.47^{* * *}$ & $7.42^{* * *}$ \\
DEC & $4.22^{* *}$ & $5.46^{* *}$ & $4.76^{* *}$ \\
DPC & $2.97^{*}$ & 0.19 & $23.14^{* * *}$ \\
DSC & 0.99 & 0.35 & $18.65^{* * *}$ \\
Control Variables & & & \\
Duality & $3.73^{*}$ & 0.25 & $9.18^{* * *}$ \\
BDSize & 0.80 & 0.61 & $6.47^{* *}$ \\
BDInd & 1.35 & 0.00 & $2.92^{*}$ \\
Ln Revenue & $7.16^{* * *}$ & 1.17 & 0.14 \\
Industry & $3.95^{* * *}$ & $4.67^{* * *}$ & $5.16^{* * *}$ \\
Year & 0.91 & 1.20 & 0.58 \\
EcqIndustry & 1.85 & $5.72^{* *}$ & $5.47^{* *}$ \\
PolIndustry & 1.38 & 0.08 & $4.11^{* *}$ \\
SocIndustry & 0.38 & 0.15 & $11.56^{* * *}$ \\
$\mathrm{R}^{2}$ & $0.46^{* * *}$ & $0.45^{* * *}$ & $0.69^{* * *}$ \\
Adjusted $\mathrm{R}^{2}$ & $0.25^{* * *}$ & $0.24^{* * *}$ & $0.58^{* * *}$ \\
\hline
\end{tabular}

The results from Table 9 also show that the interaction between directors' connections and industry has a positive and significant impact on firm financial performance.

\section{Conclusions and Discussion}

There are positive and highly significant differences among industries in terms of directors' economic, political and social connections. "Communications and Media" has the most economic and social connections, and "Consumer products and merchandising" has the most political connections.

The correlation analyses show a positive and very significant relationship between director's economic, political and social connections and the firm's main financial resources, i.e. debt level and level of shareholder equity. These correlation results confirm resource dependence theory, i.e. that the role of a director is to acquire resources for the firm. However, no significant relationship was found between directors' connections and the firm's financial performance indicators.

The results of the linear regression analysis show that only the economic and political connections of directors have a positive and significant impact on the firm's debt. None of the directors' connections have a significant impact on the firm's equity. It was also observed that the effect of financial resources (debt and equity) on financial performance is mitigated. While debt level generally has a negative impact (on ROA and ROE), equity level has a positive and significant impact only on ROE. Lastly, directors' connections have no significant impact on financial performance indicators.

Surprisingly, the results of the linear general analysis show that first, financial resources have a positive and significant impact on financial performance, and second, directors' connections mainly have a positive and significant effect on this performance.

There is one constant among the foregoing results, regardless of the statistical analysis method: directors' connections, especially economic and political, have a positive impact on firm financial resources. This supports the idea and the need to include resource dependence and social capital theories when explaining the director's role, given their respective assertions that directors help the firm acquire resources, but that they need connections to accomplish their role. 
In addition, the direct impact of the board of directors on firm financial performance is difficult to prove, as previous studies have shown. The results of our study suggest that there should be more research on the board of directors' impact on firm resource acquisition. Since directors do not intervene in the firm's operational activities (daily management), they cannot affect financial performance indicators. Therefore, their role is limited to resource acquisition, as they appear to have no influence on the disposition of resources.

\section{References}

Abdullah, S. N. (2004). Board composition, CEO duality and performance among Malaysian listed companies. Corporate Governance. http://dx.doi.org/10.1108/14720700410558871

Adler, P. S., \& Kwon, S. W. (2002). Social capital prospects for a new concept. Academy of Management Review, 27(1), 17-43.

Agrawal, A., \& Knoeber, C. R. (1996). Firm performance and mechanisms to control agency problems between managers and shareholders. Journal of Financial and Quantitative Analysis, 31(3), 377-397. http://dx.doi.org/10.2307/2331397

Ahmed, K., Hossain, M., \& Adams, M. B. (2006). The effects of board compositionand board size on the informativeness of annual accounting earnings. Corporate Governance, 14(5), 418-431. http://dx.doi.org/10.1111/j.1467-8683.2006.00515.x

Allen, M. P. (1974). The structure of interorganizational elite cooptation: interlockingcorporate directorates. American Sociological Review, 39(3), 39-406. http://dx.doi.org/10.2307/2094297

Ameer, R., Ramli, L., \& Zekaria, H. (2010). A new perspective on boardcomposition and firm performance in an emerging market. Corporate Governance, 10(5), 647-661. http://dx.doi.org/10.1108/14720701011085607

Bain, J. S. (1959). Industrial Organization. NewYork: John Wiley.

Barnhart, S. W., \& Rosenstein, S. (1998). Board composition, managerialownership, and firm performance: an empirical analysis. The Financial Review, 33(4), 1-16. http://dx.doi.org/10.1111/j.1540-6288.1998.tb01393.x

Bhagat, S., \& Black, B. (2002). The non-correlation between board independenceand long-term firm performance. Journal of Corporation Law, 27(2), 231-273.

Bonn, I. (2004). Board structure and firm performance: evidence from Australia. Journal of the Australian and New Zealand Academy of Management, 10(1), 14-24.

Bonn, I., Yoshikawa, T., \& Phan, P. H. (2004). Effects of board structure on firmperformance: a comparison between Japan and Australia. Asian Business\& Management, 3(1), 105-125. http://dx.doi.org/10.1057/palgrave.abm.9200068

Borgatti, S., \& Foster, P. (2003). The network paradigm in organizational research: A review and typology. Journal of Management, 29(6), 991-1013.

Boubakri, N., El Ghoul, S., \& Saffar, W. (2012). Cash holdings of politicallyconnected firms. TIJA Symposium, Niagara Falls.

Bourdieu, P. (1979). La distinction: critique sociale du jugement. Paris: Les Éditions de Minuit.

Bourdieu, P. (1980). Le capital social: notes provisoires. Actes de la Recherche en Sciences Sociales, 31, 2-3.

Bozec, R., \& Dia, M. (2007). Board structure and firm technical efficiency: Evidence from Canadian state-ownedenterprises. European Journal of Operational Research, 177(3), 1734-1750. http://dx.doi.org/10.1016/j.ejor.2005.10.001

Bozec, Y., Rousseau, S., \& Laurin, C. (2008). Law of incorporation and firmownership structure: The law and finance theory revisited. International Review of Law and Economics, 28, 140-149. http://dx.doi.org/10.1016/j.irle.2008.02.003

Brennan, N. (2006). Boards of directors and firm performance: is there an expectation gap? Corporate Governance, 14(6), 577-593. http://dx.doi.org/10.1111/j.1467-8683.2006.00534.x

Breton, G., \& Pesqueux, Y. (2006). Business in society or an integrated vision of governance. Society and Business Review, 1(1), 7-27. http://dx.doi.org/10.1108/17465680610643319

Burt, R. S. (1980). Cooptive corporate actor networks: a reconsideration ofinterlocking directorates involving American manufacturing. Administrative Science Quarterly, 25(4), 557-582. 
http://dx.doi.org/10.2307/2392281

Chaney, P. K., Faccio, M., \& Parsley, D. C. (2011). The quality of accountinginformation in politically connectedfirms. Journal of Accounting and Economics, 51, 58-76. http://dx.doi.org/10.1016/j.jacceco.2010.07.003

Charumilind, C., Kali, R., \& Wiwattanakantang, Y. (2006). Connected Lending: Thailand before the financial crisis. Journal of Business, 79, 181-218. http://dx.doi.org/10.1086/497410

Claessens, S., \& Yurtoglu, B. B. (2012). Corporate governance in emergingmarkets: A survey. Emerging Markets Review. http://dx.doi.org/10.1016/j.ememar.2012.03.002

Coles, J. W., McWilliams, V. B., \& Sen, N. (2001). An examinationof the relationship of governance mechanisms to performance. Journal of Management, 27(1), 23-50. http://dx.doi.org/10.1177/014920630102700102

Core, J. E., Holthausen, R. W., \& Larcker, D. F. (1999). Corporate governance, chiefexecutive officer ompensation, and firm performance. Journal of Financial Economics, 51(3), 371-406. http://dx.doi.org/10.1016/S0304-405X(98)00058-0

Coriat, B., \& Weinstein, O. (1995). Les nouvelles théories de l'entreprise. Paris: Le Livre de Poche.

Dalton, D. R., Daily, C. M., Ellstrand, A. E., \& Johnson, J. L. (1998). Meta-analyticreviews of board omposition, leadership structure, and financial performance. Strategic Management Journal, 19(3), 269-290. http://dx.doi.org/10.1002/(SICI)1097-0266(199803)19:3<269::AID-SMJ950>3.0.CO;2-K

Dalton, D. R., Daily, C. M., Johnson, J. L., \& Ellstrand, A. E. (1999). Numberof directors and financial performance: A meta-analysis. Academy of Management Journal, 42(6), 674-686. http://dx.doi.org/10.2307/256988

Dalziel, T., Gentry, R. J., \& Bowerman, M. (2011). An integrated agency-resourcedependence view of the Influenceof directors' human and relationalcapital on firms R\&D spending. The Journal of Management Studies, 48(6), 1196. http://dx.doi.org/10.1111/j.1467-6486.2010.01003.x

Davis, G. F. (1991). Agents without principles? The spread of the poison pillthrough the intercorporate network. Administrative Science Quarterly, 36(4), 583-613. http://dx.doi.org/10.2307/2393275

Davis, K., \& Blomstrom, R. L. (1971). Business, society, and environments: socialpower and social response. New York: McGraw-Hill.

Desai, A. B. (1998). A study of the relationship between changes in the corporate governance mechanism, CEO turnover, and performance in declining firms. Working paper, University of Memphis, Memphis.

Dicko, S. (2011). Réseaux de relations sociales des membres du conseil d'administration etacquisition de ressources: le cas de PowerCorporation du Canada. Unpublished doctoral dissertation, University of Quebec in Montreal, Montreal.

Dinc, I. S. (2005). Politicians and banks: Political influences on government-ownedbanks in emerging markets. Journal of Financial Economics, 77, 453-479. http://dx.doi.org/10.1016/j.jfineco.2004.06.011

Drago, C., Manestra, S., \& Santella, P. (2011). Interlocking directorships and cross-shareholdings among Italian bluechips. European Business Organization Law Review, 12(4), 619-652. http://dx.doi.org/10.1017/S1566752911400045

Dwivedi, N., \& Jain, A. K. (2005). Corporate governance and performance of Indianfirms: the effect of boardsizeand ownership. Employee Responsibilitiesand Rights Journal, 17(3), 161-172. http://dx.doi.org/10.1007/s10672-005-6939-5

Eisenberg, T., Sundgren, S., \& Wells, M. T. (1998). Larger board sizeand decreasing firm value in small firms. Journal of Financial Economics, 48(1), 35-54. http://dx.doi.org/10.1016/S0304-405X(98)00003-8

Erickson, J., Park, K. W., Reising, J., \& Shin, H. H. (2005). Board composition and firm value under concentrated ownership: the Canadian evidence. Pacific-Basin Finance Journal, 13(4), 387-410. http://dx.doi.org/10.1016/j.pacfin.2004.11.002

Faccio, M. (2006). Politically connected firms. The American Economic Review, 96(1), 369-386. http://dx.doi.org/10.1257/000282806776157704

Faccio, M., Masulis, R. W., \& Mcconnell, J. J. (2006). Political Connections and Corporate Bailouts. The Journal of Finance, LXI(6), 2597-2635. http://dx.doi.org/10.1111/j.1540-6261.2006.01000.x 
Fich, E. M., \& Lawrence, J. W. (2003). CEO compensation and turnover: the effects of mutually interlocked boards. Wake Forest Law Review, 38(3), 935-959.

Fisman, R. (2001). Estimating the value of political connections. The American Economic Review, 91(4), 1095-1102. http://dx.doi.org/10.1257/aer.91.4.1095

Fracassi, C. (2009). Corporate finance policies and social network. Working paper, SSRN.

Fracassi, C., \& Tate, G. (2010). External networking and internal firm governance. Working paper, SSRN.

Goldman, E., Rocholl, J., \& So, J. (2009). Do politically connected boards affectfirm value? The Review of Financial Studies, 22(6), 2331-2360. http://dx.doi.org/10.1093/rfs/hhn088

Granovetter, M. (2008). Sociologie économique. Paris: Éditions du Seuil.

Gupta, M., \& Fields, L. P. (2009). Board independence and corporate governance: evidence from director resignations. Journal of Business Finance \& Accounting, 36(1/2), 161-185. http://dx.doi.org/10.1111/j.1468-5957.2008.02113.x

Hermalin, B. E., \& Weisbach, M. S. (2003). Boards of directors as an endogenouslydetermined institution: a survey of the economic literature. Economic Policy Review - Federal Reserve Bank of New York, 9(1), 7-26.

Hill, S. (1995). The social organization of boards of directors. The British Journal of Sociology, 46(2), 245-278. http://dx.doi.org/10.2307/591788

Hillman, A. J., \& Dalziel, T. (2003). Boards of directors and firm performance: integrating agency and resource dependence perspectives. The Academy of Management Review, 28(3), 383-396.

Hwang, B. H., \& Kim, S. (2009). It pays to have friends. Working paper, SSRN.

Johnson, J. L., Daily, C. M., \& Ellstrand, A. E. (1996). Boards of directors: a review and research agenda. Journal of Management, 22(3), 409-438. http://dx.doi.org/10.1177/014920639602200303

Kim, Y. (2005). Board network characteristics and firm performance in Korea. Corporate Governance, 13(6), 800-808. http://dx.doi.org/10.1111/j.1467-8683.2005.00471.x

Kim, Y., \& Cannella, A. A. (2008). Toward a social capital theory of directorselection. Corporate Governance, 16(4), 282-293. http://dx.doi.org/10.1111/j.1467-8683.2008.00693.x

Klein, P., Shapiro, D., \& Young, J. (2005). Corporate governance, family ownershipand firm value: the Canadian evidence. Corporate Governance, 13(6), 769-784. http://dx.doi.org/10.1111/j.1467-8683.2005.00469.x

Lam, T. Y., \& Lee, S. K. (2008). CEO duality and firm performance: evidence fromHong Kong. Corporate Governance, 8(3), 299-317. http://dx.doi.org/10.1108/14720700810879187

Lang, J. R., \& Lockhart, D. E. (1990). Increased environmental uncertainty and changes in board linkages. Academy of Management Journal, 33(1), 106-128. http://dx.doi.org/10.2307/256354

Leng, A. C. A. (2004). The impact of corporate governance practices on firms' financial performance: evidence from Malaysian companies. ASEAN Economic Bulletin, 21(3), 308-409. http://dx.doi.org/10.1355/AE21-3D

Lester, R. H. (2003). A road less traveled: investigating the outside directors of America's corporate boards. Unpublished doctoral dissertation, University of Texas A\&M, Austin.

Lester, R. H., \& Cannella, A. A. (2006). Interorganizational familiness: how family firms use interlocking directorates to build community-level social capital. Entrepreneurship Theory and Practice, 30(6), 755-775. http://dx.doi.org/10.1111/j.1540-6520.2006.00149.x

Mak, Y. T., \& Kusnadi, Y. (2005). Size really matters: further evidence on the negative relationship between boardsize and firm value. Pacific-Basin Finance Journal, 13(3), 301-318. http://dx.doi.org/10.1016/j.pacfin.2004.09.002

Maman, D. (2000). Who accumulates directorships of big business firms in Israel? Organizational structure, social capital and human capital. Human Relations, 53(5), 603-629. http://dx.doi.org/10.1177/0018726700535001

Mizruchi, M. S. (1996). What do interlocks do? An analysis, critique, and assessment of research on interlocking directorates. Annual Review of Sociology, 22, 271-298. http://dx.doi.org/10.1146/annurev.soc.22.1.271

Mizruchi, M. S., \& Stearns, L. B. (1988). A longitudinal study of the formation of interlocking directorates. Administrative Science Quarterly, 33(2), 194-210. http://dx.doi.org/10.2307/2393055 
Nahapiet, J., \& Ghoshal, S. (1998). Social capital, intellectual capital, and the organizational advantage. Academy of management Review, 23(2), 242-271.

Nicholson, G. J., Alexander, M., \& Kiel, G. C. (2004). Defining the social capitalof the board of directors: an exploratory study. Journal of the Australianand New Zealand Academy of Management, 10(1), 54-72.

Ornstein, M. (1984). Interlocking directorates in Canada: intercorporate or class alliance? Administrative Science Quarterly, 29(2), 210-231. http://dx.doi.org/10.2307/2393174

Ortiz-de-Mandojana, N., Aragón-Correa, J. A., Delgado-Ceballos, J., \& Ferrón-Vílchez, V. (2012). The effect of director interlocks on firmsadoption of proactive environmental strategies. Corporate Governance: An International Review, 20(2), 164-178. http://dx.doi.org/10.1111/j.1467-8683.2011.00893.x

Oxelheim, L., \& Randoy, T. (2003). The impact of foreign board membershipon firm value. Journal of Banking \& Finance, 27(12), 2369-2392. http://dx.doi.org/10.1016/S0378-4266(02)00395-3

Pfeffer, J. (1972). Size and composition of corporate boards-of-directors the organization and its environment. Administrative Science Quarterly, 17(2), 218-228. http://dx.doi.org/10.2307/2393956

Pfeffer, J. (1973). Size, composition, and function of hospital boards-of-directors a study of organization-environment linkage. Administrative Science Quarterly, 18(3), 349-364. http://dx.doi.org/10.2307/2391668

Pfeffer, J. (1982). Organizations and organization theory. Stanford University: Pitman Boston.

Pfeffer, J., \& Salancik, G. R. (1978). The external control of organizations: a resource dependence perspective. New York: Harper \& Row.

Pombo, C., \& Gutiérrez, L. H. (2011). Outside directors, board interlocks and firm performance: Empirical evidence from Colombian business groups. Journal of Economics and Business, 63(4), 251. http://dx.doi.org/10.1016/j.jeconbus.2011.01.002

Richardson, R. J. (1987). Directorship interlocks and corporate profitability. Administrative Science Quarterly, 32(3), 367-386. http://dx.doi.org/10.2307/2392910

Rosenstein, S., \& Wyatt, J. G. (1990). Outside directors, board independence, and shareholder wealth. Journal of Financial Economics, 26(2), 175-191. http://dx.doi.org/10.1016/0304-405X(90)90002-H

Roy, M. J. (2009). Linking board types to key board roles. International Journal of Business Governance and ethics, 4(3), 298-312. http://dx.doi.org/10.1504/JJBGE.2009.023334

Schellenger, M. H., Wood, D. D., \& Tashakori, A. (1989). Board of directorcomposition, shareholder wealth, and dividends. Journal of Management, 15(3), 457-467. http://dx.doi.org/10.1177/014920638901500308

Useem, M. (1979). The social organization of the American business eliteand participation of corporation directors in the governance of Americaninstitutions. American Sociological Review, 44(4), 553-577. http://dx.doi.org/10.2307/2094587

Wills-Johnson, N. (2008). The networked firm: a framework for RBV. Journalof Management Development, 27(2), 214-224. http://dx.doi.org/10.1108/02621710810849344

Yammeesri, J., \& Herath, S. K. (2010). Boards characteristics and corporate value: Evidence from Thailand. Corporate Governance, 10(3), 279-292. http://dx.doi.org/10.1108/14720701011051910

Yang, Z. (2011). Do political connections add value to audit firms? Evidence from IPO Audits in China. Paper presented at the 26th CAR Conference, Calgary.

Yeo, H. J., Pochet, C., \& Alcouffe, A. (2003). CEO reciprocal interlocks in Frenchcorporations. Journal of Management \& Governance, 7(1), 87-108. http://dx.doi.org/10.1023/A:1022442602193

Yermack, D. (1996). Higher market valuation of companies with a small board of directors. Journal of Financial Economics, 40(2), 185-211. http://dx.doi.org/10.1016/0304-405X(95)00844-5 